\title{
Paradoksalne ruchy fałdów głosowych jako czynnościowa przyczyna duszności krtaniowej i chrypki
}

\author{
Paradoxical vocal fold movements as a functional cause \\ of laryngeal dyspnoea and hoarseness
}

\begin{abstract}
Słowa kluczowe: paradoksalne ruchy fałdów głosowych, duszność krtaniowa, chrypka, stridor, zaburzenia psychosomatyczne
\end{abstract}

Keywords: paradoxical vocal fold movements, laryngeal dyspnoea, hoarseness, stridor, psychosomatic disorders

\section{Wprowadzenie}

Zaburzenia psychosomatyczne dotyczą kilkunastu procent społeczeństwa. W podstawowej opiece zdrowotnej ich częstość szacuje się na 10-25\% [Faravelli i wsp., 1997, s. 24-29; de Waal i wsp., 2004, s. 470-476; Roca i wsp., 2009, s. 52-58]. Efektorami są najczęściej: układ pokarmowy, sercowo-naczyniowy, nerwowy, oddechowy. Wśród objawów konwersyjnych w zakresie narządów laryngologicznych typowe są: tzw. globus histericus oraz dysfonia lub afonia psychogenna. Paradoksalne ruchy fałdów głosowych (ang. paradoxical vocal fold movements - PVFM) to kompleksowy, heterogenny zespół objawów o zróżnicowanej etiologii i manifestacji klinicznej. Jest

\footnotetext{
* Uniwersytet Medyczny w Łodzi, Klinika Otolaryngologii, Onkologii Laryngologicznej, Audiologii i Foniatrii, ul. Żeromskiego 113, 90-549 Łódź; e-mail: marzena.mielczarek@umed.lodz.pl, https:// orcid.org/0000-0001-5400-6094

** Uniwersytet Medyczny w Łodzi, Klinika Otolaryngologii, Onkologii Laryngologicznej, Audiologii i Foniatrii, ul. Żeromskiego 113, 90-549 Łódź, e-mail: hanna.zielinska-blizniewska@umed.lodz.pl, https://orcid.org/0000-0001-8311-5513

*** Uniwersytet Medyczny w Łodzi, Klinika Otolaryngologii, Onkologii Laryngologicznej, Audiologii i Foniatrii, ul. Żeromskiego 113, 90-549 Łódź; e-mail: jurek.olszewski@umed.lodz.pl, https://orcid.org/0000-0002-8868-9679
} 
to zaburzenie czynnościowe, które oznacza patologiczne przywiedzenie fałdów głosowych w fazie wdechowej i/lub wydechowej, co skutkuje obturacją dróg oddechowych i dusznością. Inną najczęściej spotykaną w literaturze nazwą jest dysfunkcja fatdów glosowych (ang. vocal cord dysfunction) [Christopher i wsp., 1983, s. 1566-1570]. Jednostka ta może być klinicznie skrajną postacią psychosomatyzacji, w zakresie laryngologicznym prowadzącą do objawów zwężenia głośni. Pacjent prezentuje wówczas obraz obustronnego porażenia krtani, przebiegającego ze świstem krtaniowym (stridorem), z którego powodu wykonywana jest tracheotomia w trybie nagłym.

Pierwsze doniesienia na temat PVFM pochodzą z XIX wieku i określają tę patologię jako „fałszywy krup” [za Bahrainwala, Simon, 2001, s. 8-13]. W 1842 roku została ona opisana jako skurcz krtani dotyczący histerycznych osobników żeńskich, później sklasyfikowano ją jako stridor Munchausena [Patterson, Schatz, Horton, 1974, s. 307-310]. Roy Patterson, Michael Schatz i Mark Hormon opisali przypadek trzydziestotrzyletniej pacjentki hospitalizowanej piętnaście razy z powodu duszności wdechowej ze stridorem, nieuzasadnionej patologią organiczną. Inne pojawiające się w literaturze określenia to: czynnościowa obturacja dróg oddechowych, stridor psychogenny, spastyczny krup [Appelblatt, Baker, 1981, s. 305-306; Collett, Brancatisano, Engel, 1983, s. 500-504; Skinner, Bradley, 1989, s. 383-385; Patel i wsp., 2015, s. 566-584].

\section{Epidemiologia}

Częstość występowania tego zaburzenia pozostaje nieoszacowana między innymi ze względu na brak jednoznacznych kryteriów diagnostycznych oraz - mimo upływu wielu lat od pierwszego doniesienia - wciąż ograniczonej wiedzy w tym zakresie. Co ciekawe, częstość występowania PVFM w grupie pacjentów zgłaszających się po pomoc doraźną do szpitala z objawami duszności lub zaostrzenia astmy oszacowana została na 1,7-22\% [Ciccolella i wsp., 1997, s. 155; Kenn, Schmitz, 1997, s. 14-18; Jain i wsp., 2006, s. 207-212]. Literatura wydaje się raczej zgodna co do większej częstości PVFM u dorosłych niż u dzieci (71\% a 29\%) oraz u kobiet niż u mężczyzn (2 lub 3 : 1) [Brugman, 2003, s. 167; Morris, Allan, Perkins, 2006, s. 73-86]. Co więcej, uważa się, że wykonywany zawód może być czynnikiem modyfikującym częstość występowania PVFM. Predysponowane są kobiety pracujące w sektorze ochrony zdrowia, atleci oraz osoby w trakcie aktywnej służby wojskowej [Martin i wsp., 1987, s. 332-337; Newman, Mason, Schmaling, 1995, s. 1382-1386; Morris i wsp., 1999, s. 1676-1682; Rundell, Spiering, 2003, s. 468-474; Rhodes, 2008, s. 608-613]. 


\section{Etiologia}

Mimo zidentyfikowania różnorodnych czynników współistniejących z PVFM nie wyróżniono dotychczas tego, który byłby bezpośrednio odpowiedzialny za to zaburzenie. W literaturze podawanych jest kilka klasyfikacji PVFM ze względu na prawdopodobny czynnik etiologiczny. James Koufman wskazuje sześć grup przyczyn tego zaburzenia [Koufman, Block, 2008, s. 327-334]. Najczęstszą jest według niego refluks gardłowo-krtaniowy (ang. laryngopharyngeal reflux - LPR). PVFM trwa wówczas minuty lub godziny, rzadziej dni, na ogół nie wymaga interwencji na drogach oddechowych, występuje jako przejściowa reakcja chemoreceptorów nadgłośni (zależna od nerwu błędnego) na kontakt z treścią żołądkową. Paradoksalne przywiedzenie fałdów głosowych pojawia się po posiłku, w trakcie ćwiczeń fizycznych, schylania, w nocy (czasem nawet wybudza pacjentów ze snu). W tej grupie pacjentów LPR manifestuje się na ogół uczuciem zgagi, trudnościami w przełykaniu, pochrząkiwaniem, kaszlem, uczuciem „kuli” w gardle i spływania wydzieliny po tylnej ścianie gardła, może przebiegać w sposób niemy lub z przemijającą chrypką. Christopher Loughlin i James Koufman zaobserwowali całkowite ustąpienie objawów po włączeniu farmakoterapii (dwa razy dziennie inhibitor pompy protonowej) [Loughlin, Koufman, 1996, s. 1502-1505].

Wśród innych czynników sprzyjających nadreaktywności krtani, a tym samym nieprawidłowemu, odruchowemu przywiedzeniu fałdów głosowych, wymieniane są: infekcje wirusowe górnych dróg oddechowych, alergie, czynniki drażniące (tj. dym tytoniowy, alkohol, kofeina, kurz, suche powietrze, mówienie, opary chemiczne) [Dunn, Katial, Hoyte, 2015]. W literaturze PVFM określane jest także jako zespół nadwrażliwej krtani [Morrison, Rammage, Emami, 1999, s. 447-455).

Dystonia krtaniowa o typie oddechowym i dysfonia spastyczna należą do tego samego kręgu dystonii krtaniowych, jednak rzadko współistnieją. Obie postaci manifestują się zaburzeniami oddychania, jednak ta pierwsza pojawia się w trakcie dnia, nie daje dolegliwości w nocy, pacjent zgłasza uczucie relatywnego upośledzenia drożności dróg oddechowych trwające cały dzień, nasilające się w trakcie czynności wymagających głębokiego oddychania. Spastyczna manifestuje się zaś zaburzeniami oddechowymi w trakcie mówienia. Ulgę przynosi podanie toksyny botulinowej do fałdu głosowego.

Mechanizm wystąpienia PVFM w przebiegu astmy nie jest do końca poznany, choć opisywany jest wysoki wskaźnik (56\%) jej współistnienia u osób w PVFM [Newman, Mason, Schmaling, 1995, s. 1382-1386]. Brana jest pod uwagę dysfunkcja odruchów zależnych od nerwu błędnego, jak również same zmiany głośni w przebiegu astmy [Collett, Brancatisano, Konno, 1983, s. 719-723]. Szczególne znacznie dla diagnostyki różnicowej PVFM w przebiegu astmy ma wystąpienie duszności wdechowej, która jest typowa dla obturacji górnych dróg oddechowych, nie dla astmy.

PVFM uwarunkowane nieprawidłowościami w pniu mózgu mogą być związane wyłącznie z patologią ośrodkową (np. urazem głowy, udarem tylnego dołu czaszki) 
lub mogą współistnieć z obustronnym porażeniem mięśni odwodzących krtani, epizodami bezdechów lub zespołem bezdechów ośrodkowych. Tak uwarunkowane objawy obturacji dróg oddechowych współistnieją z innymi objawami neurologicznymi, występują także we śnie i wymagają interwencji chirurgicznej.

W literaturze PVFM opisuje się jako reakcję polekową na niektóre neuroleptyki (np. haloperidol, chlorpromazynę) lub leki stosowane do znieczulenia ogólnego [Koek, Pi, 1989, s. 359-364]. Stridor indukowany lekami z grupy neuroleptyków na ogół współistnieje z objawami pozapiramidowymi (np. sztywnością mięśsni, zaburzeniami ruchowymi) i ustępuje po podaniu leków antycholinergicznych [Stoelting, 1987].

W wyniku zaburzeń psychiatrycznych i psychogennych stridor występuje rzadko. Możliwe psychogenne przyczyny PVFM to: ciężki stres u atletów (związany $\mathrm{z}$ uczestniczeniem w zawodach), wykorzystywanie seksualne, fizyczne lub emocjonalne. $\mathrm{Z}$ kolei najczęstsze zaburzenia psychiatryczne to: lęk, depresja, zaburzenia obsesyjno-kompulsywne, hipochondria, zaburzenia osobowości i zaburzenia konwersyjne [Ramírez, León, Rivera, 1986, s. 716-721; Brown, Merritt, Evans, 1988, s. 308-310; Freedman, Rosenberg, Schmaling, 1991, s. 295-298; Lacy, McManis, 1994, s. 213-223; Tajchman, Gitterman, 1996, s. 105-108; Powell i wsp., 2000, s. 29-34; Lawrence, 2007, s. 96-104; Koufman, Block, 2008, s. 327-334]. Pacjenci z dodatnim wywiadem psychiatrycznym prezentują niestałe objawy, które nagle pojawiają się i ustępują. Koufman podaje przykład normalizacji funkcji krtani pacjenta i ustąpienia stridoru w trakcie czytania na głos dłuższego tekstu. Kładzie nacisk na konieczność wykluczenia innych przyczyn przed postawieniem diagnozy psychogennych PVFM oraz powołanie wielospecjalistycznego zespołu diagnozującego, w którego skład wchodzą: otolaryngolog, logopeda, psycholog i psychiatra [Koufman, Block, 2008, s. 327-334].

\section{Symptomatologia}

PVFM to heterogenna grupa także pod względem prezentacji objawów klinicznych. Pacjenci na ogół skarżą się na brak tchu, duszność, niemożność wdechu, skrócenie oddechu i duszność wysiłkową, dławienie, uczucie ucisku w obrębie szyi, z niemożnością nabrania powietrza, uczucie duszenia (które może wywołać atak paniki i wtórne nasilenie zaburzeń oddychania). Dodatkowo objawom mogą towarzyszyć świsty, gwizdy oddechowe, stridor, kaszel, zmiany głosu, uczucie ucisku w klatce piersiowej [Newman, Mason, Schmaling, 1995, s. 1382-1386; Brugman, 2003, s. 167]. 


\section{Diagnostyka}

W literaturze zwraca się uwagę na trudności diagnostyczne PVFM. W związku z niejednokrotnie dramatyczną manifestacją objawów pacjenci są przyjmowani do szpitala w trybie nagłym. W początkowym okresie choroby w takich warunkach zalecana jest diagnostyka i leczenie. Z drugiej zaś strony - z powodu epizodycznego przebiegu - objawy nie zawsze są możliwe do uchwycenia w trakcie badania. W takiej sytuacji można podjąć próbę prowokacji objawów przez forsowne zachowania, tj. szybkie oddychanie, naprzemienną fonację samogłosek i pociągnie nosem, kaszel, pochrząkiwanie, głośną fonację lub wysiłek fizyczny z użyciem bieżni czy roweru stacjonarnego [Koufman, Block, 2008, s. 327-334]. Warto także zauważyć, że - w związku z czynnościowym charakterem zaburzenia - prawidłowy obraz krtani i brak objawów w trakcie badania nie wyklucza PVFM [Landwehr i wsp., 1996, s. 971-974].

Klasyczna laryngoskopia pośrednia w sytuacji nagłej duszności może być trudna do wykonania, co więcej - istnieje możliwość wyindukowania objawów PVFM [Ng, 2017, s. 19-22]. Preferowanym badaniem jest zatem endoskopia krtani przez nos (nasofiberoskopia), w której typowo obserwuje się przywiedzenie fałdów głosowych w fazie wdechowej (medializację fałdów głosowych powyżej 50\%) z niedomykalnością w tylnym odcinku głośni [Mathers-Schmidt, 2001; Koufman, Block, 2008, s. 327-334]. Klinicznie pacjent prezentuje objawy duszności w związku z obturacją dróg oddechowych na poziomie głośni. Mimo to zwraca się uwagę na częste mylenie i konieczność różnicowania tej jednostki patologicznej z astmą. Czynnikiem różnicującym jest tu brak reakcji na leki rozszerzające oskrzela oraz negatywne bądź niespójne wyniki prób prowokacyjnych. Dodatkowo badania obrazowe dolnych dróg oddechowych nie wykazują patologii, a poziomy saturacji pozostają niezmienione [Franca, 2014, s. 2169-2173]. Badania akustyczne głosu wykazują niespecyficzne zmiany, tj. skrócenie czasu fonacji, zawężenie zakresu głosu, podwyższenie wskaźników jitter i shimmer [Zelcer i wsp., 2002, s. 601-608; Vertigan i wsp., 2008, s. 210-216]. W badaniach biochemicznych krwi uzyskuje się wartości prawidłowe, choć z powodu często prezentowanej hiperwentylacji może wystąpić hipo- lub hiperkapnia [Niven i wsp., 1992, s. 513-516].

W diagnostyce różnicowej należy uwzględnić obustronne porażenie fałdów głosowych, laryngospazm, dysfonię spastyczną, aspirację ciała obcego, przewlekłą obturacyjną chorobę płuc, nowotwór krtani, dystonię krtani. W celu wykluczenia patologii ośrodkowego układu nerwowego wykonuje się badanie MRI.

\section{Postępowanie terapeutyczne}

Postępowanie można podzielić na właściwe dla ostrej fazy choroby oraz długoterminowe. Prawidłowe leczenie uzależnione jest każdorazowo od trafnej diagnozy. Niestety, u pacjentów z PVFM prezentujących nagłą duszność krtaniową ze stridorem 
niejednokrotnie wykonywana jest tracheotomia. W sytuacji rozpoznania PVFM pacjenta należy upewnić o łagodnej naturze objawów oraz o prawidłowych poziomach tlenu we krwi, mimo odczuwanej duszności [Vertigan i wsp., 2008]. Inną propozycją jest wizualizacja funkcji krtani w wideolaryngoskopii, tak aby pacjent mógł zaobserwować przywiedzenie fałdów głosowych w trakcie wystąpienia duszności [Vertigan i wsp., 2008]. W celu otwarcia głośni Scott Kramer i współautorzy zalecają także zadania niewokalne, takie jak wąchanie, wdech nosem, wydech z zaciśniętymi ustami. Techniki relaksacyjne mają na celu kontrolę mentalną nad oddychaniem, jak również redukcję stresu [Kramer i wsp., 2017, s. 1531-1537]. Co więcej, uważa się, że mogą pomóc pacjentowi kontrolować sytuacje zaostrzenia objawów PVFM, na przykład w trakcie infekcji lub niepokoju i lęku. W tym samym celu można stosować benzodiazepiny, oddychanie mieszanką tlenu i helu czy nebulizację z lidokainy, która wpływa na zmniejszenie wysiłku oddechowego i przynosi ulgę pacjentom z PVFM [Ibrahim i wsp., 2007, s. 164-172].

Postępowanie długoterminowe jest wielodyscyplinarne. Obejmuje farmakoterapię, psychoterapię, leczenie psychiatryczne oraz rehabilitację mowy i głosu. Leczenie farmakologiczne, oprócz relaksacji i leczenia psychiatrycznego, dotyczy także czynników współistniejących (np. refluksu, alergii, zapalenia zatok, astmy, lęku). Zakres postępowania logopedycznego obejmuje ocenę kliniczną pacjenta, diagnozowanie, edukację, poradnictwo, terapię głosu i trening panowania nad objawami oddechowymi. Logopeda prowadzi terapię panowania nad krtanią (ang. laryngeal control therapy lub respiratory retraining therapy). Wykorzystywane są do tego techniki pośrednie i bezpośrednie. Bezpośrednie skupiają się na poszczególnych komponentach narządu głosu, a na celu mają rehabilitację głosu, utrzymanie prawidłowej drożności dróg oddechowych, relaksację gardła, ćwiczenia sapania (dyszenia) i biofeedback. W literaturze wymienia się: ćwiczenia koncentracji na wydechu, relaksację mięśni jamy ustnej i gardła, edukację pacjenta i zapewnienie o tym, że kondycja PVFM znajduje się pod kontrolą, ćwiczenia oddychania przeponowego, szerokiego oddychania, skoordynowanego oddychania piersiowo-brzusznego, biofeedback, psychoedukację i poradnictwo, trening mięśni wdechowych [Jain i wsp., 2006].

Pośrednie techniki rehabilitacji głosu mają z kolei prowadzić do modyfikacji zachowań wpływających na głos, na przykład przez edukację pacjenta, zapewnienie go o łagodnej naturze dolegliwości, relaksację, higienę głosu.

\section{Prezentacja przypadku}

Trzydziestotrzyletnia kobieta została przyjęta do Kliniki Otolaryngologii, Onkologii Laryngologicznej, Audiologii i Foniatrii Uniwersytetu Medycznego w Łodzi w trybie nagłym z powodu wdechowej duszności wysiłkowej przebiegającej ze stridorem. Z wywiadu wynikało, że wyżej wymienione objawy występowały od dwóch tygodni, tj. od czasu 
zdiagnozowania u chorej zapalenia płuc. Ponadto była leczona z powodu epilepsji od około piętnastu lat. Pacjentka nie zgłosiła innych chorób i stosowania leków na stałe. Przy przyjęciu w laryngoskopii pośredniej oraz w badaniu wideolaryngostroboskopowym (VLS) stwierdzono obustronne porażenie fałdów głosowych, z ich przypośrodkowym ustawieniem. Głos był ochrypły w stopniu G2 (umiarkowana chrypka).

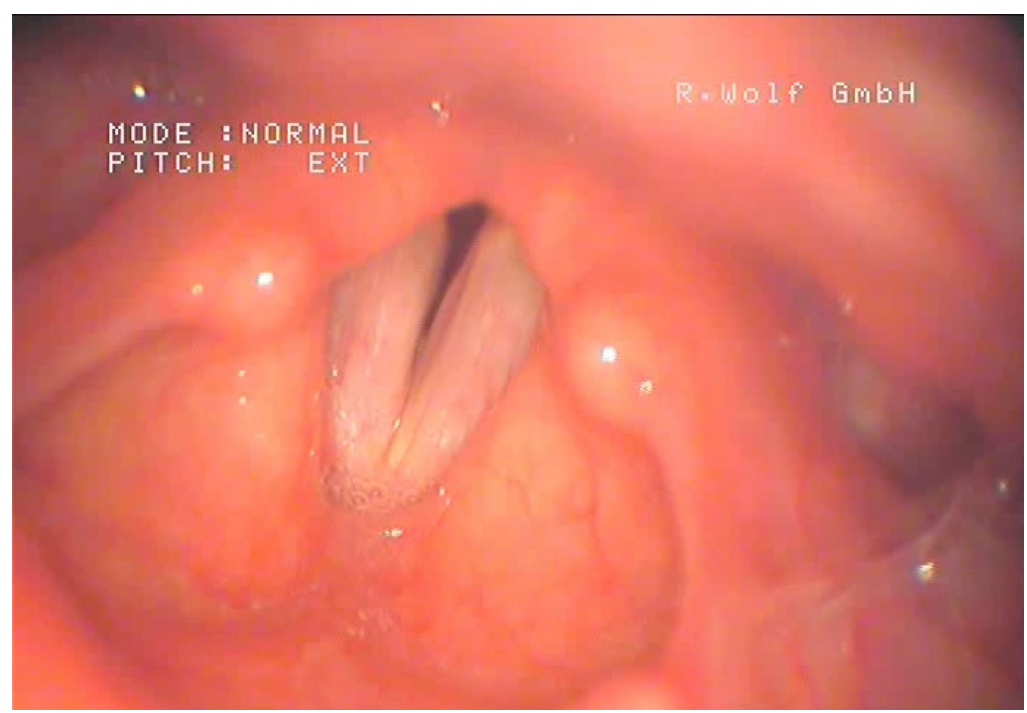

Rysunek 1. Obraz wideolaryngoskopowy przy przyjęciu do szpitala; faza oddechowa; fałdy głosowe w pozycji przywiedzionej; szpara głośni wąska

Źródło: badania własne

W klinice w trybie pilnym przeprowadzono diagnostykę obrazową (CT z kontrastem) szyi i klatki piersiowej, wykluczając patologie organiczne, mogące być przyczyną obustronnego porażenia fałdów głosowych. Badania laboratoryjne (morfologia krwi, wskaźniki stanu zapalnego, gospodarka wapniowa) nie wykazały istotnych odchyleń od stanu prawidłowego.

W związku z dobrym i stabilnym stanem klinicznym chorej postanowiono włączyć intensywne leczenie farmakologiczne, odraczając decyzję o tracheotomii. $\mathrm{W}$ drugiej dobie hospitalizacji objawy prezentowane przez chorą nie uległy zmianie. W laryngoskopii pośredniej chora prezentowała taki sam obraz jak w dniu poprzednim, jednakże ze stridorem słyszalnym wyłącznie w fazie wydechowej. Powtórzono badanie wideolaryngoskopowe, poprzedzając je badaniem podmiotowym. $\mathrm{W}$ trakcie rozmowy pacjentka była spokojna, ale płaczliwa, poinformowała lekarza, że od dwóch lat leczy się z powodu depresji - bez poprawy nastroju. W trakcie rozmowy słyszalny wcześniej stridor stopniowo ustąpił. W VLS uzyskano pełne odwiedzenie fałdów głosowych $w$ fazie oddechowej i niepełne zwarcie fonacyjne $\mathrm{w} 1 / 2$ tylnej części głośni w fazie fonacyjnej. 


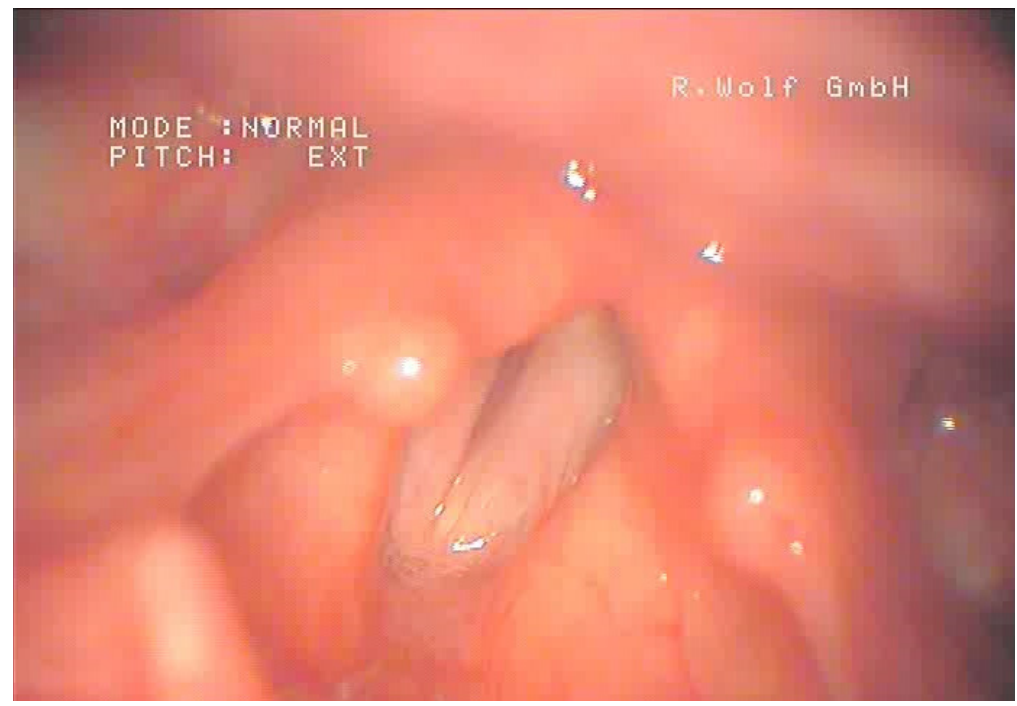

Rysunek 2. Obraz wideolaryngoskopowy przy przyjęciu do szpitala; faza fonacyjna; niepełne zwarcie fonacyjne prawie na całej długości głośni

\section{Źródło: badania własne}

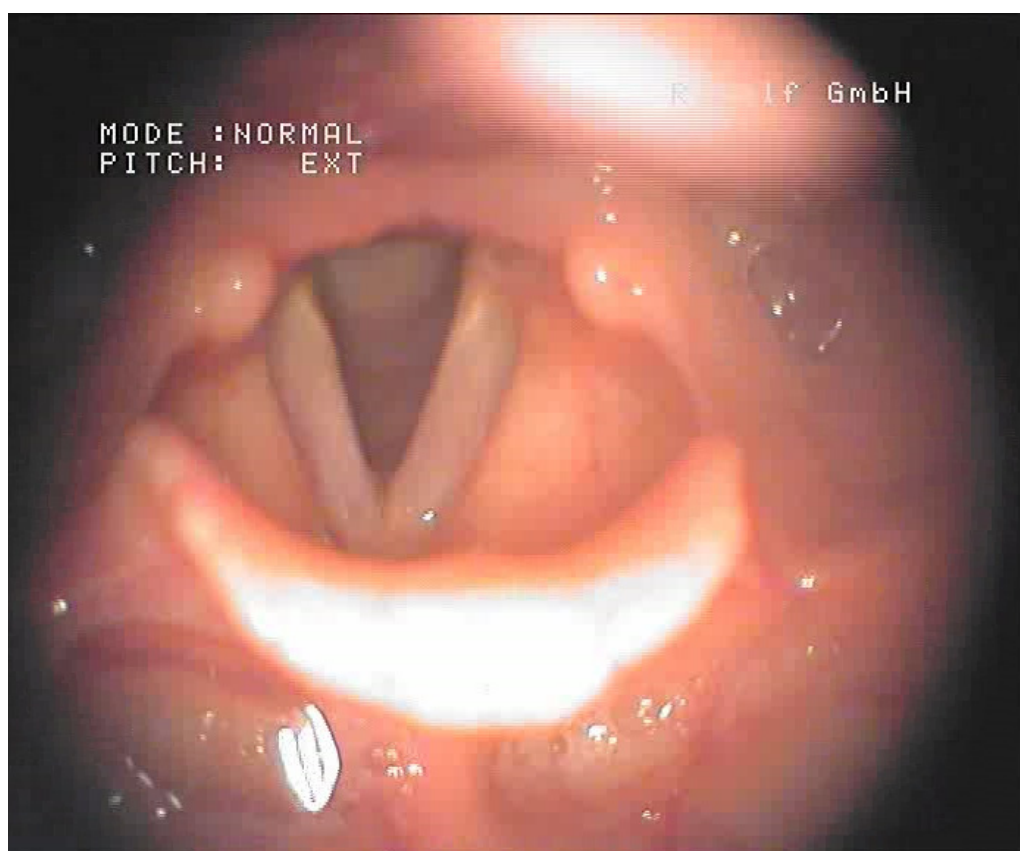

Rysunek 3. Obraz wideolaryngoskopowy przy wypisie; faza oddechowa; pełne odwiedzenie fałdów głosowych

Źródło: badania własne 


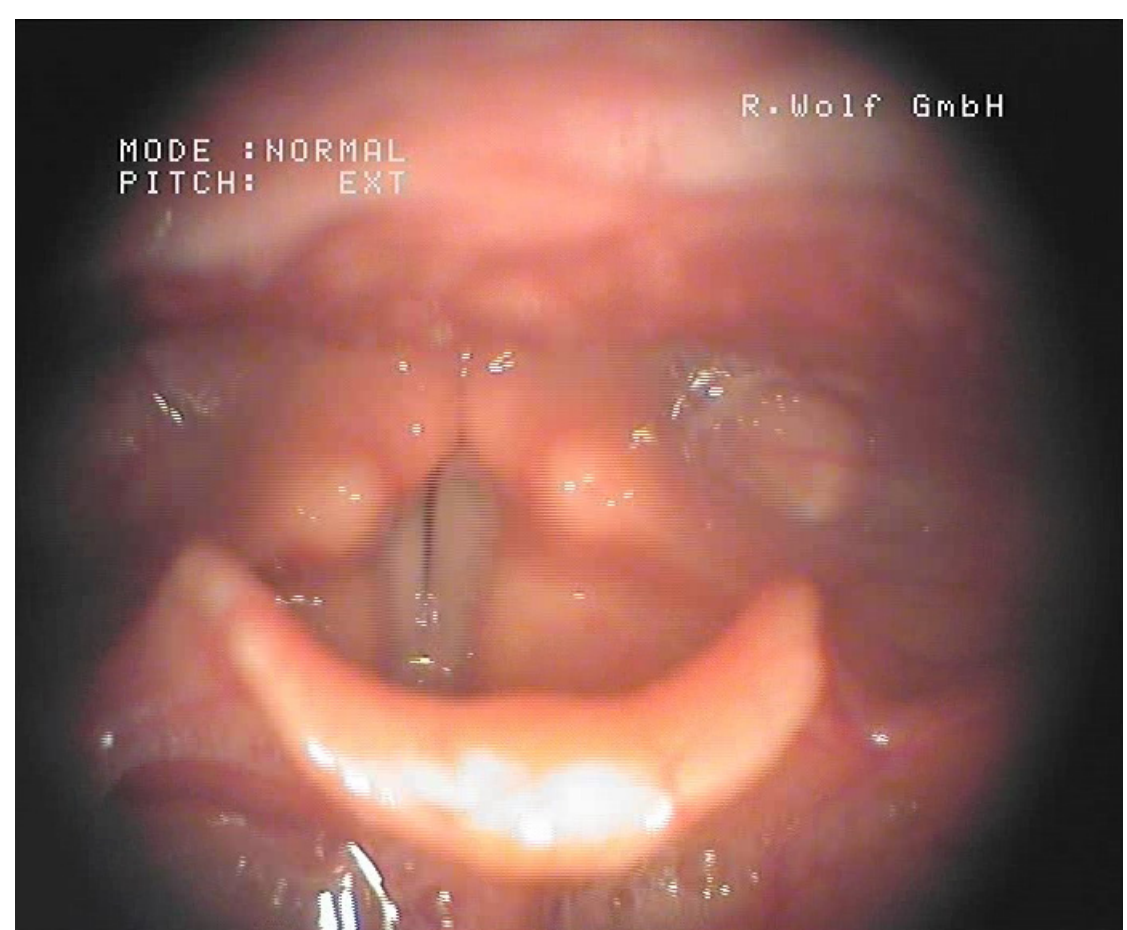

Rysunek 4. Obraz wideolaryngoskopowy przy wypisie; faza fonacyjna; niepełne zwarcie fonacyjne W $1 \frac{1}{2}$ tylnej części głośni

Źródło: badania własne

Pacjentka została skonsultowana psychiatrycznie. Rozpoznano u niej zaburzenia depresyjne i lękowe. Zmodyfikowano leczenie farmakologiczne. Wykonano badanie obrazowe ośrodkowego układu nerwowego (MRI z kontrastem), wykluczając patologię organiczną. Następnego dnia chora nie miała duszności, stridoru, natomiast utrzymywała się u niej chrypka (G2R2B0A0S1/2 - stopień chrypki umiarkowany, szorstkość głosu umiarkowana, napięcie głosu na granicy lekkiego i umiarkowanego, cechy B i A nieobecne) ${ }^{1}$. Po okresie obserwacji pacjentka została wypisana z kliniki w stanie ogólnym i miejscowym dobrym. Zalecenia wypisowe obejmowały kontrolę foniatryczną, kontynuację zmodyfikowanego leczenia psychiatrycznego oraz psychoterapię.

1 GRBAS - czterostopniowa (0-3) skala służąca do oceny chrypki (0 - brak cechy, 1 - lekkie nasilenie, 2 - umiarkowane, 3 - cecha w stopniu ciężkim): G (ang. grade) - stopień chrypki, R (ang. roughness) - szorstkość głosu, B (ang. breathiness) - głos chuchający, A (ang. asthenic) - głos słaby, S (ang. strained) - głos napięty. 


\section{Podsumowanie}

Zaburzenia psychosomatyczne, będące przyczyną dolegliwości z pogranicza foniatryczno-logopedycznego lub otolaryngologicznych, są dość rzadkie. Najczęściej spotykane w codziennej praktyce ambulatoryjnej i klinicznej są afonia i dysfonia psychogenna. Z kolei duszność jest jednym z najbardziej gwałtownych i relatywnie częstych stanów nagłych w praktyce otolaryngologicznej i wymaga zdecydowanego postępowania lekarskiego. Jednak duszność spowodowana patologicznym przywiedzeniem fałdów głosowych wyłączenie na tle czynnościowym (psychogennym) jest wyjątkowo rzadka. Przypadek kliniczny pacjentki z dusznością, stridorem i chrypką na tle nieorganicznym stanowi skrajną manifestację zaburzeń psychicznych wymagających pilnej interwencji specjalistów psychiatrii. Jednak praktyka pokazuje, że może ona nie wystarczyć do unormowania głosu. W związku z tym pacjenci wymagają - w dalszym etapie lub równolegle prowadzonej - intensywnej, niejednokrotnie długotrwałej i kompleksowej terapii głosu.

Literatura

Appelblatt N.H., Baker S.R., 1981, Functional upper airway obstruction, „Archives of Otolaryngology", no. 107, s. 305-306.

Bahrainwala A.H., Simon M.R., 2001, Wheezing and vocal cord dysfunction mimicking asthma, "Current Opinion in Pulmonary Medicine”, vol. 7(1), s. 8-13.

Brown T.M., Merritt W.D., Evans D.L., 1988, Psychogenic vocal cord dysfunction masquerading as asthma, „The Journal of Nervous and Mental Disease”, no. 176, s. 308-310.

Brugman S.M., 2003, The many faces of vocal cord dysfunction: what 36 years of literature tell us, „American Journal of Respiratory and Critical Care Medicine”, vol. 167(7).

Christopher K.L., Wood R.P., Eckert R.C., Blager F.B., Raney R.A., Souhrada J.F., 1983, Vocal-cord dysfunction presenting as asthma, „New England Journal of Medicine”, no. 308, s. 1566-1570.

Ciccolella D.E., Brennan K.J., Borbely B., Criner G.J., 1997, Identification of vocal cord dysfunction (VCD) and other diagnoses in patients admitted to an inner city university hospital asthma center. Abstract, „American Journal of Respiratory and Critical Care Medicine”, vol. 155: A82.

Collett P.W., Brancatisano T., Engel L.A., 1983, Spasmodic croup in the adult, „The American Review of Respiratory Disease", no. 127, s. 500-504.

Collett P.W., Brancatisano T., Konno K., 1983, Changes in glottic aperture during bronchial asthma, "American Review of Respiratory Diseases", no. 128, s. 719-723.

Dunn N.M., Katial R.K., Hoyte F.C.L., 2015, Vocal cord dysfunction: a review, „Asthma Research and Practice", vol. 1, no. 9.

Faravelli C., Salvatori S., Galassi F., Aiazzi L., Drei C., Cabras P., 1997, Epidemiology of somatoform disorders: a community survey in Florence, „Social Psychiatry and Psychiatric Epidemiology”, no. 32, s. 24-29.

Franca M.C., 2014, Differential diagnosis in paradoxical vocal fold movement (PVFM): an interdisciplinary task, „International Journal of Pediatric Otorhinolaryngology”, vol. 78(12), s. $2169-2173$. 
Freedman M.R., Rosenberg S.J., Schmaling K.B., 1991, Childhood sexual abuse in patients with paradoxical vocal cord dysfunction, „The Journal of Nervous and Mental Disease”, no. 179, s. $295-298$.

Ibrahim W.H., Gheriani H.A., Almohamed A.A., Raza T., 2007, Paradoxical vocal cord motion disorder: past, present and future, „Postgraduate Medical Journal”, vol. 83(977), s. 164-172.

Jain S., Bandi V., Officer T., Wolley M., Guntupalli K.K., 2006, Role of vocal cord function and dysfunction in patients presenting with symptoms of acute asthma exacerbation, „Journal of Asthma", vol. 43(3), s. 207-212.

Kenn K., Schmitz M., 1997, Vocal cord dysfunction, an important differential diagnosis of severe and implausible bronchial asthma, „Pneumologie”, vol. 51(1), s. 14-18.

Koek R.J., Pi E.H., 1989, Acute laryngeal dystonic reactions to neuroleptics, „Psychosomatics”, no. 30, s. 359-364.

Koufman J.A., Block C. (2008), Differential diagnosis of paradoxical vocal fold movement, „American Journal of Speech-Language Pathology”, vol. 17(4), s. 327-334.

Kramer S., Silva B. de, Forrest L.A., Matrka L., 2017, Does treatment of paradoxical vocal fold movement disorder decrease asthma medication use?, „Laryngoscope”, vol. 127(7), s. 1531-1537.

Lacy T.J., McManis S.E., 1994, Psychogenic stridor, „General Hospital Psychiatry”, no. 16, s. 213-223.

Landwehr L.P., Wood R.P., Blager F.B., Milgrom H., 1996, Vocal cord dysfunction mimicking exercise-induced bronchospasm in adolescents, „Pediatrics”, vol. 98(5), s. 971-974.

Lawrence S.G., 2007, Laryngeal dyskinesia: An under-recognized condition, „Emergency Medicine Australia", no. 19, s. 96-104.

Loughlin C.J., Koufman J.A., 1996, Paroxysmal laryngospasm secondary to gastroesophageal reflux, „Laryngoscope”, no. 106, s. 1502-1505.

Martin R.J., Blager F.B., Gay M.L., Wood R.P., 1987, Paradoxic vocal cord motion in presumed asthmatics, „Seminars in Respiratory Medicine”, no. 8, s. 332-337.

Mathers-Schmidt B.A., 2001, Paradoxical Vocal Fold Motion: A Tutorial on a Complex Disorder and the Speech-Language, „American Journal of Speech-Language Pathology”, vol. 10(2), s. 111-125.

Morris M.J., Allan P.F., Perkins P.J., 2006, Vocal cord dysfunction, „Obstructive Airways Disease”, no. 13 , s. $73-86$.

Morris M.J., Deal L.E., Bean D.R., Grbach V.X., Morgan J.A., 1999, Vocal cord dysfunction in patients with exertional dyspnea, „Chest”, no. 116, s. 1676-1682.

Morrison M., Rammage L., Emami A.J., 1999, The irritable larynx syndrome, „Journal of Voice”, no. 13 , s. $447-455$.

Newman K.B., Mason U.G., Schmaling K.B., 1995, Clinical features of vocal cord dysfunction, „American Journal of Respiratory and Critical Care Medicine”, no. 152, s. 1382-1386.

$\mathrm{Ng}$ T.T., 2017, The forgotten cause of stridor in the emergency department, „Open Access Emergency Medicine", vol. 16, no. 9, s. 19-22.

Niven R.M., Roberts T., Pickering C.A., Webb A.K., 1992, Functional upper airways obstruction presenting as asthma, „Respiratory Medicine”, vol. 86(6), s. 513-516.

Patel R.R., Venediktov R., Schooling T., Wang B., 2015, Evidence-Based Systematic Review: Effects of Speech-Language Pathology Treatment for Individuals with Paradoxical Vocal Fold Motion, „American Journal of Speech-Language Pathology”, vol. 24(3), s. 566-584.

Patterson R., Schatz M., Horton M., 1974, Munchausen's stridor: non-organic laryngeal obstruction, "Clinical \& Experimental Allergy”, vol. 4(3), s. 307-310.

Powell D.M., Karanfilov B.I., Beechler K.B., Treole K., Trudeau M.D., Forrest A., 2000, Paradoxical vocal cord dysfunction in juveniles, „Archives of Otolaryngology - Head and Neck Surgery”, no. 126 , s. 29-34.

Ramírez R.J., León I., Rivera L.M., 1986, Episodic laryngeal dyskinesia: Clinical and psychiatric characterization, „Chest”, no. 90, s. 716-721. 
Rhodes RK., 2008, Diagnosing vocal cord dysfunction in young athletes, „Journal of the American Association of Nurse Practitioners", vol. 20(12), s. 608-613.

Roca M., Gili M., Garcia-Garcia M., Salva J., Vives M., Garcia Campayo J., Comas A., 2009, Prevalence and comorbidity of common mental disorders in primary care, "Journal of Affective Disorders", no. 119, s. 52-58.

Rundell K.W., Spiering B.A., 2003, Inspiratory stridor in elite athletes, „Chest”, no. 123, s. 468-474.

Skinner D.W., Bradley P.J., 1989, Psychogenic stridor, „Journal of Laryngology and Otology”, no. 103, s. 383-385.

Stoelting R.K., 1987, Pharmacology and physiology in anesthetic practice, Lippincott, Philadelphia.

Tajchman U.W., Gitterman B., 1996, Vocal cord dysfunction associated with sexual abuse, „Clinical Pediatrics", vol. 35(2), s. 105-108.

Vertigan A.E., Theodoros D.G., Winkworth A.L., Gibson P.G., 2008, Acoustic and electroglottographic voice characteristics in chronic cough and paradoxical vocal fold movement, „Folia Phoniatrica et Logopaedica”, vol. 60(4), s. 210-216.

Waal M.W. de, Arnold I.A., Eekhof J.A., Hemert A.M. van, 2004, Somatoform disorders in general practice: prevalence, functional impairment and comorbidity with anxiety and depressive disorders, „British Journal of Psychiatry”, no. 184, s. 470-476.

Zelcer S., Henri C., Tewfik T.L., Mazer B., 2002, Multidimensional voice program analysis $(M D V P)$ and the diagnosis of pediatric vocal cord dysfunction, „Annals of Allergy, Asthma \& Immunology", no. 88, s. 601-608.

\section{Streszczenie}

Paradoksalne ruchy fałdów głosowych (ang. paradoxical vocal fold movements - PVFM) to kompleksowy, heterogenny zespół objawów o zróżnicowanej etiologii i manifestacji klinicznej. Jest to zaburzenie czynnościowe, które oznacza patologiczne przywiedzenie fałdów głosowych w fazie wdechowej i/lub wydechowej, co skutkuje obturacją dróg oddechowych i dusznością. Jednostka ta może być klinicznie skrajną postacią psychosomatyzacji, w zakresie laryngologicznym prowadzącą do objawów zwężenia głośni. W artykule zaprezentowano przypadek młodej kobiety, która zgłosiła się do szpitala z powodu duszności ze stridorem oraz chrypki. Przedstawiono obraz kliniczny, diagnostykę i postępowanie terapeutyczne.

\section{Abstract}

Paradoxical vocal fold movements is a complex and heterogenic syndrome. It is a functional disorder manifesting itself as a pathological adduction of vocal folds in the inspiratory and/ or expiratory phase, resulting in airway obstruction and dyspnoea. This pathology may appear as an extreme form of psychosomatization involving otolaryngological organs, leading to dyspnoea and stridor. The paper presents the case of a young woman who was admitted to hospital due to dyspnoea, stridor and hoarseness. The paper presents the clinical picture, diagnostics and therapeutic procedures which were used. 